\title{
ASSOCIATION BETWEEN MATRIX METALLOPROTEINASE-1 -1607 1G/2G POLYMORPHISM AND CHRONIC PERIODONTITIS IN INDONESIAN POPULATION
}

\author{
RAHMATUL HAYATI ${ }^{1}$, ANTONIUS WINOTO SUHARTONO ${ }^{1}$, SRI LELYATI MASULILI ${ }^{2}$, CHRISTOPHER TALBOT ${ }^{3}$, \\ ELZA IBRAHIM AUERKARI ${ }^{*} *$
}

${ }^{1}$ Department of Oral Biology, Faculty of Dentistry, Universitas Indonesia, Jakarta, Indonesia. ${ }^{2}$ Department of Periodontology Faculty of Dentistry, Universitas Indonesia, Jakarta, Indonesia. ${ }^{3}$ Department of Genetics, University of Leicester, Leicester, UK.

Email: eiauerkari@yahoo.com

Received: 02 October 2009, Revised and Accepted: 24 December 2019

ABSTRACT

Objective: This study aimed to identify the distribution of matrix metalloproteinase (MMP)-1 -1607 1G/2G alleles and genotypes in subjects with chronic periodontitis and healthy subjects in a sample of Indonesian population and assess the possible association of this polymorphism with susceptibility to chronic periodontitis.

Methods: Genomic DNA samples were obtained from 200 Indonesian males aged 33-78 years old, comprising 100 chronic periodontitis patients and 100 healthy controls. DNA fragments were amplified by a polymerase chain reaction and analyzed by restriction fragment length polymorphism. Results were analyzed by Chi-square test.

Results: The frequency of the $2 \mathrm{G}$ allele was high both in subjects with periodontitis (87\%) and in controls (91\%). Analysis of MMP-1 genotype $(-16071 G / 2 G)$ showed no significant difference between the chronic periodontitis and healthy groups $(p>0.05)$.

Conclusion: The result found no association between MMP-1 -1607 1G/2G polymorphism and susceptibility to chronic periodontitis in Indonesian subjects.

Keywords: Periodontitis, Matrix metalloproteinases-1, Genetic polymorphism, Indonesia.

(c) 2020 The Authors. Published by Innovare Academic Sciences Pvt Ltd. This is an open access article under the CC BY license (http://creativecommons. org/licenses/by/4. 0/) DOI: http://dx.doi.org/10.22159/ijap.2020.v12s1.ARL026

\section{INTRODUCTION}

Periodontitis is an inflammatory disease of the supporting dental tissue that is initiated by specific microorganisms or groups of specific microorganisms, ultimately causing periodontal apparatus destruction by means of loss of clinical attachment (CAL) [1-4]. In addition, we have investigated the prevalence of periodontal diseases in Indonesia, finding that chronic periodontitis was the most common form of periodontal disease at $75.2 \%$; a weak positive correlation was found between age and chronic periodontitis [5]. Taken together, these findings suggest that genetics might contribute to susceptibility to periodontal disease.

Matrix metalloproteinases (MMPs) are a family of proteolytic enzymes that play a major role in periodontal tissue degradation. At present, about 28 types of MMPs have been identified, some of which are found in inflamed periodontal tissues and gingival crevicular fluid [6]. Studies showed that the $2 \mathrm{G}$ allele significantly increases the transcription activity of MMP- 1 compared to the $1 \mathrm{G}$ allele [6]. However, the results are inconsistent across studies. Variation in the disease, sample selection, race, and ethnic background may all contribute to the inconsistent findings across the previous studies. Therefore, further study is needed to examine the distribution of MMP-1 genotypes in other populations to confirm if it is indeed a genetic marker of chronic periodontitis.

The present study aimed to identify the distribution of MMP-1 alleles and genotypes in Indonesian subjects with chronic periodontitis and healthy controls and also to identify the possible association of the MMP-1 promoter polymorphism with susceptibility to chronic periodontitis.

\section{METHODS}

Subjects and sampling

Two-hundred Indonesian male adults (aged 33-78 years old) participated in this study, including 100 subjects with chronic periodontitis and 100 subjects with healthy periodontal conditions as controls recruited through the dental faculty hospital (RSGM-P FKG UI). Periodontal examinations were performed by a periodontal specialist resident and then standardized [7]. Patients who had probing depth $>3 \mathrm{~mm}$, clinical attachment loss $>5 \mathrm{~mm}$, and/or bleeding on probing positive were selected as chronic periodontitis subjects. Dental and/or panoramic radiographs were used to confirm the diagnosis of chronic periodontitis. Patients with systemic diseases and a history of antibiotic use within the past 6 months were excluded from this study. Peripheral blood samples were obtained from direct venipuncture, transferred to ethylenediaminetetraacetic acid (EDTA) tubes, and stored at $-20^{\circ} \mathrm{C}$ until DNA extraction using the technique by Auerkari et al. [8,9]. This study was approved by the Ethics Committee of the Faculty of Dentistry, University of Indonesia.

Polymerase chain reaction (PCR)

MMP-1 genotype was determined using specific forward and reverse primers for $1 G / 2 G$ alleles. The sequences of the PCR primers were forward 5'-TCGTGAGAATGTCTTCCCATT-3' and reverse 5'-TCTTGGATTGATTTGAGATAAGTGAAATC-3'. The target size of the PCR product is $118 \mathrm{bp}$. These primer pairs have been used in the previous studies [8,9]. PCR was carried out in a total volume of $20 \mu \mathrm{L}$ containing $0.75 \mu \mathrm{L}$ genomic DNA, $0.75 \mu \mathrm{L}$ of each primer (PT. Genetika Science Indonesia, Jakarta, Indonesia), $7.75 \mu \mathrm{L} \mathrm{ddH_{2 }} \mathrm{O}$, and $10 \mu \mathrm{L}$ PCR ready mix (KAPA Biosystems, Massachusetts, K1006, USA). The PCR cycling conditions were $1 \mathrm{~min}$ at $95^{\circ} \mathrm{C}$, followed by 35 cycles of $30 \mathrm{~s}$ at $95^{\circ} \mathrm{C}$, $30 \mathrm{~s}$ at $55^{\circ} \mathrm{C}$, and $30 \mathrm{~s}$ at $72^{\circ} \mathrm{C}$, with a final extension of $72^{\circ} \mathrm{C}$ for $5 \mathrm{~min}$. 
Restriction fragment length polymorphism (RFLP)

This study used restriction enzyme XmnI to digest the $1 \mathrm{G}$ alleles, while $2 \mathrm{G}$ alleles do not contain the recognition site due to the guanine (G) insertion [4,10]. A total volume of $18 \mu \mathrm{L}$ RFLP mixture contained $10 \mu \mathrm{L}$ PCR product, $1 \mu \mathrm{L} \mathrm{XmnI} \mathrm{(1000} \mathrm{U/mL,} \mathrm{CutSmart}{ }^{\mathrm{TM}}$, New England Biolabs, Inc.), $2 \mu \mathrm{L}$ nuclear exact buffer, and $5 \mu \mathrm{L} \mathrm{ddH}_{2} \mathrm{O}$. The mixtures were incubated at $37^{\circ} \mathrm{C}$ overnight. Restriction enzyme XmnI digested $1 \mathrm{G}$ allele and created two fragments of $89 \mathrm{bp}$ and $29 \mathrm{bp}$, but it could not digest $2 \mathrm{G}$ allele due to the insertion of the guanine base. This singlenucleotide polymorphism (SNP) caused mismatches in the reverse primer annealed sequence for the XmnI site.

\section{Gel electrophoresis}

This study used 1.5\% agarose gel (TopVision Agarose, Thermo Fisher Scientific Inc., Massachusetts, R0491, USA) for PCR product and 3\% for RFLP product, dissolved in 1x TAE buffer (0.089 M Tris, $0.089 \mathrm{M}$ acetic acid, and 0.5 M EDTA pH 8.0). 1.5 $\mu \mathrm{L}$ of GelRed ${ }^{\mathrm{TM}}$ was added as a dye for the DNA fragments. As a DNA marker, $3 \mu \mathrm{L} 50$ bp DNA ladder (Invitrogen ${ }^{\mathrm{TM}}$, Thermo Fisher Scientific Inc., Massachusetts, 10416014, USA) was added to one well. Electrophoresis was performed at $80 \mathrm{~V}$ and $400 \mathrm{~mA}$ for 45 min for PCR products and $60 \mathrm{~V}$ for $60 \mathrm{~min}$ for RFLP products.

\section{Statistical analysis}

Statistical analysis was performed using the SPSS 17.0 statistical package (SPSS Inc., Chicago, IL, USA). Differences in allele and genotype frequencies between the periodontitis and control groups were assessed by Chi-square test. $\mathrm{p}<0.05$ was considered statistically significant. The risk associated with individual alleles and genotypes was calculated as the odds ratio (OR) with 95\% confidence interval (95\% CI).

\section{RESULTS}

All PCR products were detected and visualized by electrophoresis at 118 bp (Figs. 1 and 2). Thus, 1G/1G homozygotes showed a single $89 \mathrm{bp}$ band, 2G/2G homozygotes displayed a single $118 \mathrm{bp}$ band, and $1 \mathrm{G} / 2 \mathrm{G}$ heterozygotes exhibited two bands of $118 \mathrm{bp}$ and $89 \mathrm{bp}$. The polymorphism was in Hardy-Weinberg equilibrium.

The allele and genotype frequencies are presented in Tables 1 and 2 . Table 1 shows that the $2 \mathrm{G}$ allele was most common in both the chronic periodontitis (87\%) and control subjects (91\%). The presence of the $2 \mathrm{G}$ allele was not related to increased risk of chronic periodontitis $(\mathrm{p}=0.201,0 R=0.662,95 \% \mathrm{CI}=0.350-1.250)$. Table 2 shows that the $2 \mathrm{G} / 2 \mathrm{G}$ genotype occurred in $86 \%$ of chronic periodontitis subjects, which is slightly lower than in control subjects (87\%). This genotype was not significantly associated with increased risk of chronic periodontitis $(\mathrm{p}=0.076, \mathrm{OR}=0.386,95 \% \mathrm{CI}=0.131-1.140)$.

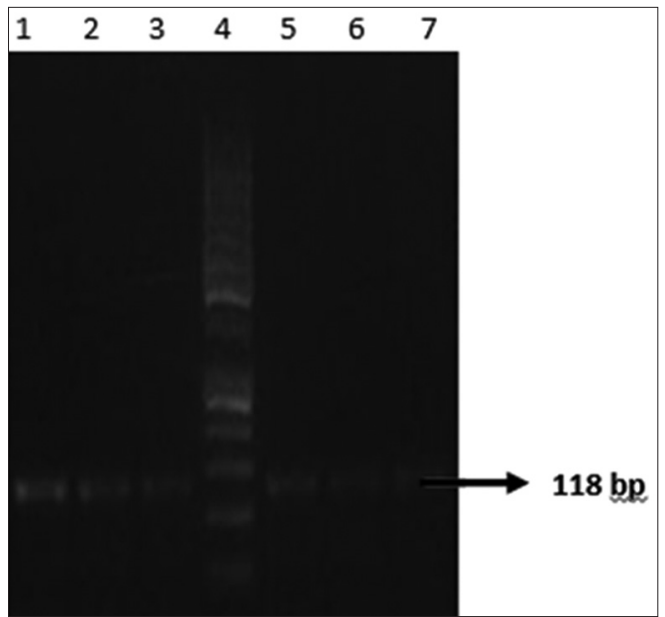

Fig. 1: Electrophoresis visualization of polymerase chain reaction products. Single bands were seen at 118 bp (lanes 1-3, 5-7) and the size marker (lane 4 ) is a 50 bp ladder

\section{DISCUSSION}

Periodontitis is a multifactorial disease; aside from interaction between periodontal pathogens and host immunoinflammatory response, genetic factors may be associated with the pathogenesis of periodontal disease $[2,3]$. The loss of clinical attachment (CAL) in periodontitis is caused by the destruction of periodontal tissues initiated by group(s) of Gram-negative and anaerobic bacteria that colonize the subgingival [4]. The host responds to this situation by activating immune cells and releasing inflammatory cytokines and enzymes. By contrast, chronic periodontitis is the slow, progressive destruction of the periodontal apparatus and is more likely related to the accumulation of dental plaque [1].

It is known that MMP-1, also known as collagenase, is an MMP family that can cleave interstitial collagen types I and III, which are the predominant types of interstitial collagen in the periodontium, and it is found at higher

Table 1: Distribution of matrix metalloproteinases-1 alleles in control and chronic periodontitis subjects

\begin{tabular}{|c|c|c|c|c|c|c|}
\hline \multirow[t]{2}{*}{ Alleles } & \multicolumn{2}{|c|}{ Control } & \multicolumn{2}{|c|}{$\begin{array}{l}\text { Chronic } \\
\text { periodontitis }\end{array}$} & \multirow[t]{2}{*}{ p-value } & \multirow[t]{2}{*}{$\begin{array}{l}\text { Odds ratio } \\
(95 \% \mathrm{CI})\end{array}$} \\
\hline & $\mathbf{n}$ & $\%$ & $\mathbf{n}$ & $\%$ & & \\
\hline $1 \mathrm{G}$ & 18 & 9.0 & 26 & 13.0 & 0.201 & \\
\hline $2 \mathrm{G}$ & 182 & 91.0 & 174 & 87.0 & & $\begin{array}{l}0.662 \\
(\mathrm{CI}=0.350-1.250)\end{array}$ \\
\hline
\end{tabular}

CI: Confidence interval

Table 2: Distribution of matrix metalloproteinases-1 genotypes in control and chronic periodontitis subjects

\begin{tabular}{|c|c|c|c|c|c|c|}
\hline \multirow[t]{2}{*}{ Genotypes } & \multicolumn{2}{|c|}{ Control } & \multicolumn{2}{|c|}{$\begin{array}{l}\text { Chronic } \\
\text { periodontitis }\end{array}$} & \multirow[t]{2}{*}{ p-value } & \multirow[t]{2}{*}{$\begin{array}{l}\text { Odds ratio } \\
(95 \% \mathrm{CI})\end{array}$} \\
\hline & $\mathbf{n}$ & $\%$ & $\mathbf{n}$ & $\%$ & & \\
\hline $1 \mathrm{G} / 1 \mathrm{G}$ & 5 & 5.0 & 12 & 12.0 & 0.076 & \\
\hline $1 G / 2 G$ & 8 & 8.0 & 2 & 2.0 & & \\
\hline $2 \mathrm{G} / 2 \mathrm{G}$ & 87 & 87.0 & 86 & 86.0 & & $\begin{array}{l}0.386 \\
(\mathrm{CI}=0.131-1.140)\end{array}$ \\
\hline
\end{tabular}

CI: Confidence interval

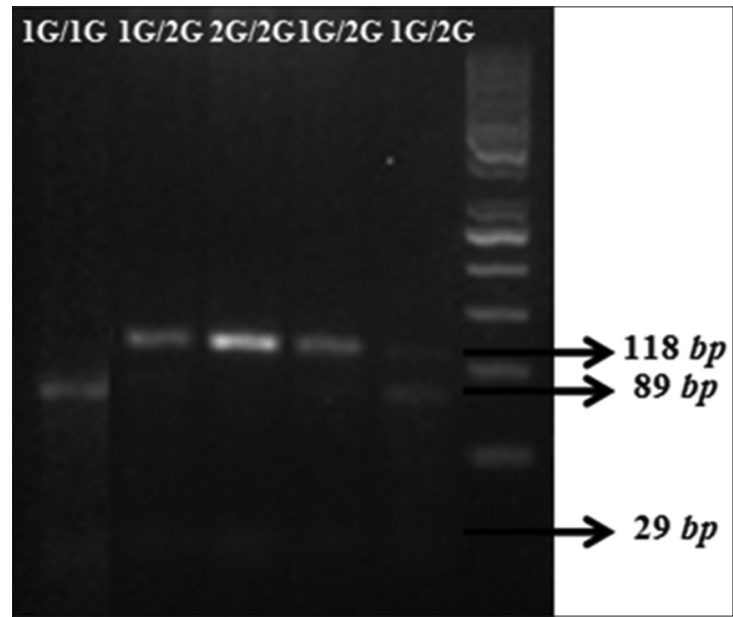

Fig. 2: Electrophoresis visualization of matrix metalloproteinases-1 -1607 1G/2G polymorphisms performed by XmnI. XmnI digested the $1 \mathrm{G}$ allele and created two fragments of $89 \mathrm{bp}$ and $29 \mathrm{bp}$. 1G/1G homozygotes appeared as two bands of $89 \mathrm{bp}$ and $29 \mathrm{bp}, 2 \mathrm{G} / 2 \mathrm{G}$ homozygotes appeared as a single $118 \mathrm{bp}$ band, and $1 \mathrm{G} / 2 \mathrm{G}$ heterozygotes appeared as three bands of $118 \mathrm{bp}, 89 \mathrm{bp}$, and $29 \mathrm{bp}$. The size marker is a $50 \mathrm{bp}$ ladder 
levels in periodontitis sites [4,6]. MMP-1 is secreted by connective tissue cells and macrophages. Genetic variation in the promoter region of the MMP-1 gene can influence transcription levels of MMP-1, thereby altering susceptibility to and severity of periodontitis [4]. With respect to an SNP located at $-1607 \mathrm{bp}$, where there is a guanine (G) base insertion, creates a mismatched Ets-binding site. A study of the Chinese population showed that the $2 \mathrm{G}$ allele may be associated with aggressive periodontitis [4], while a study of the Brazilian population concluded that it was not [10]. This contradiction may occur because polymorphisms, especially SNPs, are population specific [11]

To the best of our knowledge, this is the first study of MMP-1 polymorphism and periodontitis risk in Indonesian population. Our findings did not suggest a relationship between MMP-1 genotype distribution and risk of chronic periodontitis, which is consistent with findings reported by both Astolfi et al. (2006) and Itagaki et al. (2004) [10,12-14].

However, our study is limited by the sample size of 200 males. Given the complex relationship between genetic polymorphisms and periodontal destruction, further study with a larger sample is needed to confirm this finding.

\section{CONCLUSION}

No association between MMP-1 -1607 1G/2G polymorphism and susceptibility to chronic periodontitis was found in Indonesian subjects. However, further studies need to be conducted.

\section{ACKNOWLEDGMENTS}

This study was supported by the Ministry of Research, Technology and Higher Education through the Directorate of Research and Public Service University of Indonesia.

\section{CONFLICTS OF INTEREST}

All authors have none to declare.

\section{REFERENCES}

1. Newman MG, Takei HH, Carranza FA. Carranza's Clinical Periodontology. St. Louis: Elsevier/Saunders; 2012. p. 825
2. Genco RJ, Borgnakke WS. Risk factors for periodontal disease. Periodontol 2000 2013;62:59-94.

3. da Silva MK, de Carvalho AC, Alves EH, da Silva FR, Pessoa LD, Vasconcelos FP. Genetic factors and the risk of periodontitis development: Finding from a systematic review composed of 13 studies of meta-analysis with 71,531 participants. Int $\mathrm{J}$ Dent 2017;2017:1914073

4. Cao Z, Li C, Jin L, Corbet EF. Association of matrix metalloproteinase-1 promoter polymorphism with generalized aggressive periodontitis in a Chinese population. J Periodontal Res 2005;40:427-31.

5. Tadjoedin M, Fitri AH, Kuswandani SO, Sulijaya B, Soeroso Y. The correlation between age and peridontal diseases. J Int Dent Med Res 2017; $10: 327$

6. Sbardella D, Fasciglione GF, Gioia M, Ciaccio C, Tundo GR, Marini S, et al. Human matrix metalloproteinases: An ubiquitarian class of enzymes involved in several pathological processes. Mol Aspects Med 2012;33:119-208.

7. Sulijaya B, Masulili SL, Lessang R, Soeroso Y, Auerkari EI. Existence of human beta defensin-1 peptide on periodontal disease: An updated review based on case-control and cross-sectional studies. Asian J Pharm Clin Res 2016;9:174.

8. Auerkari EI, Suryandari DA, Umami SS, Kusdhany LS, Siregar TW, Rahardjo TB, et al. Gene promoter polymorphism of RUNX2 and risk of osteoporosis in postmenopausal Indonesian women. SAGE Open Med 2014;2:2050312114531571. Available from: https://doi. org/10.1177/2050312114531571

9. Auerkari E, Suhartono A, Djamal N, Verisqa F, Suryandari D, Kusdhany L, et al. CRP and IL-1B gene polymorphisms and CRP in blood in periodontal disease. Open Dent J 2013;7:88-93.

10. Astolfi CM, Shinohara AL, da Silva RA, Santos MC, Line SR, de Souza AP. Genetic polymorphisms in the MMP-1 and MMP-3 gene may contribute to chronic periodontitis in a Brazilian population. J Clin Periodontol 2006;33:699-703.

11. Karthikeyan R, Peeran SW, Murugan M, Awidat K, Basheer O, Al Mugrabi MH. Single nucleotide polymorphisms and periodontitis. Dent Med Res 2014;2:3.

12. Souza AP, Line SR. The biology of matrix metalloproteinases. Rev FOB 2002; 10:1-6.

13. Oh HS, Kim OS, Kim YJ, Chung HJ. MMP-1 promoter polymorphism in Korean with generalized aggressive periodontitis. J Korean Acad Periodontol 2009;39:269.

14. Itagaki M, Kubota T, Tai H, Shimada Y, Morozumi T, Yamazaki K. Matrix metalloproteinase-1 and -3 gene promoter polymorphisms in Japanese patients with periodontitis. J Clin Periodontol 2004;31:764-9. 